\author{
RUCH MIEJSKI SMART CITY NA PODKARPACIU. \\ NOWOCZESNA INICJATYWA SPOLECZNA \\ CZY DZIALALNOŚĆ PARTYJNA POD ZMIENIONYM SZYLDEM
}

\title{
Wstęp
}

Tak sformułowany temat rozważań wymaga wyjaśnienia zawartych w nim pojęć, czyli ruchu miejskiego i koncepcji smart cities. Z politologicznego (ale i socjologicznego) punktu widzenia ruch miejski jest relatywnie nowym pojęciem. Współcześni badacze wywodzą je z nowych ruchów społecznych ${ }^{1}$ ukształtowanych pod koniec lat sześćdziesiątych XX wieku, niektórzy z nich dokonują uszczegółowienia ruchów miejskich w postaci wskazania konkretnej typologii ruchów społecznych - kontestacyjnych, protestu czy ruchów alternatywnych ${ }^{2}$. W praktyce ruchy te tworzą wyzwania zarówno dla polityki, jak i konkretnego obszaru interakcji zachodzącej między społeczeństwem a różnymi instytucjami (agendami) władzy i administracji publicznej.

Obecne pojmowanie ruchu miejskiego odnosi się „do problemów wielkiej i małej skali: roli i granic własności prywatnej, kwestii mieszkaniowej, prawa do

* dr Dominik Szczepański, Uniwersytet Rzeszowski, e-mail: dominik1947@tlen.pl

1 Przez pojęcie ruchu społecznego należy rozumieć świadome, zbiorowe dążenie i ,zespołową działalność ludzi zmierzających do osiągnięcia wspólnego celu", natomiast jego podstawowym celem bywa zbiorowy, nadrzędny interes uczestników działań. Por. E. Olszewski, Ruch spoleczny, w: Encyklopedia politologii, t. 4, Myśl społeczna i ruchy polityczne współczesnego świata, red. M. Żmigrodzki, Zakamycze 2000, s. 331.

2 T. Paleczny, Nowe ruchy społeczne, Kraków 2010, s. 25-31; Wolność, równość, odmienność. Nowe ruchy społeczne w Polsce poczatku XXI wieku, red. I. Krzemiński, Warszawa 2006, s. 11; M. Żakowska, Ruchy miejskie a tradycja ruchów spolecznych, „Animacja Życia Publicznego. Zeszyty Centrum Badań Społeczności i Polityk Lokalnych” 2013, nr 3, s. 15-16; W. Przybylski, Problemy ruchów miejskich, w: Demokratyzacja miasta. Debaty Fundacji im. Stefana Batorego, www.batory.org.pl/upload/publikacje/DEBATY_Demokratyzacja\%20miasta.pdf (1.09..2015). 
miasta i przestrzeni miejskiej. Proponują oparcie w wartościach uniwersalnych - prawach człowieka, obywatela, mieszkańca. Zdejmują tabu z reakcji niezadowolenia, gniewu, oburzenia. Proponują przyjęcie własnej - alternatywnej - podmiotowości. Wskazują cele, rozpowszechniają wzorce organizacyjne i całościowe modele działania"3. Kluczowymi wyznacznikami tych ruchów jest kwestia tożsamości miejskiego społeczeństwa podlegająca nieustannym (re)konstrukcjom, a także odmienne sposoby pojmowania przez miejskich aktywistów „,problemów miejskich" i takiego samego interpretowania tego - czym jest i czyje jest „prawo do miasta" (the right to the city). Jak zauważył trafnie Przemysław Pluciński: „W walkach o «dobrze urządzone miasto» uczestniczą bardzo różni aktorzy: sami obywatele oraz aktywiści, ale też władze samorządowe, artyści i instytucje kultury. Moda na miejskość staje się też elementem kapitalizmu kulturowego. Postacie takiego uczestnictwa też są zróżnicowane: od polityki protestu (z której wyrasta część miejskich środowisk aktywistycznych), przez ograniczające się do określonych przestrzeni strategie «naprawcze» i różnorodne strategie partycypacyjne, aż po rozmaite sposoby zagnieżdżania się w systemie"4. Doskonałym przykładem takiego funkcjonowania ruchów miejskich w Polsce, zwłaszcza w systemie zinstytucjonalizowanej polityki, był ich czynny udział w wyborach samorządowych w 2010 i w 2014 roku$^{5}$. Na bazie tego zaangażowania w 2011 roku obserwowaliśmy powstanie I ogólnopolskiego Kongresu Ruchów Miejskich, którego głównym celem było m.in. ,zsieciowanie organizacji działających w obszarze polityki miejskiej i wspólne wypracowanie dalszych strategii działań na rzecz poprawy jakości życia w mieście". Uczestniczyło w nim łącznie 48 organizacji i wielu aktywistów miejskich oraz obserwatorów, natomiast wymiernym rezultatem tego kongresu było wspólne wypracowanie Tez Miejskich zawierających kluczowe problemy polskich miast oraz zapowiadające rozpoczęcie ogólnopolskiej debaty dotyczącej kondycji przyszłego ich rozwoju?

Z kolei koncepcja smart cities, czyli inteligentnych miast, dotyczy przekształcenia miast w zrównoważone oraz wydajne struktury zwłaszcza w takich

\footnotetext{
3 K. Herbst, Ruchy nieformalne a kierunki rozwoju ekonomii społecznej. Rekomendacje dla polityk publicznych, Warszawa 2013, s. 8.

4 P. Pluciński, Im lepiej, tym gorzej albo widmo kryzysu miejskich ruchów społecznych, „Ruch Prawniczy, Ekonomiczny i Socjologiczny” 2015, nr 1, s. 410.

5 Szerzej na ten temat zob. J. Erbel, Ruchy miejskie jako nowa forma zaangażowania spotecznego, http://wladzasadzenia.pl/2014/4/ruchy-miejskie-jako-nowa-forma-zaangazowania-spolecznego.pdf (2.09.2015).

6 Ibidem.

7 Szerzej zob. Tezy miejskie, http://kongresruchowmiejskich.pl/tezy-miejskie (14.09.2015).
} 
dziedzinach jak przesył informacji i skuteczne wykorzystywanie nowych technologii, zużycie energii, organizacja transportu czy redukcja zanieczyszczeń (przede wszystkim $\mathrm{CO}_{2}$ ). Ponadto koncepcja zakłada uczynienie miast bardziej konkurencyjnymi przy jednoczesnym wykorzystaniu następujących dziedzin: „smart economy - inteligentna gospodarka (konkurencyjność), smart mobility - inteligentny transport (transport i ICT), smart environment - inteligentne środowisko (zasoby naturalne, gospodarka odpadami), smart people - inteligentni ludzie (kapitał społeczny i ludzki, wiedza, umiejętności, kompetencje, mądrość), smart living - inteligentne mieszkanie (poziom życia), smart governance - inteligentne zarządzanie i uczestnictwo"s.

Spełnienie przez miasto powyższych kryteriów zapewnia mieszkańcom przyjazną przestrzeń do życia, czyste i ekologiczne środowisko, infrastrukturę techniczną, a także organizację życia kulturalnego. Oprócz tego miasto staje się katalizatorem zmian. Dzięki wdrożeniu koncepcji smart cities miasto potrafi być samowystarczalne w procesie utylizacji odpadów, produkcji żywności czy właściwego gospodarowania energią. Do tego jednak potrzeba zmian w mentalności mieszkańców miast, uruchomienia odpowiednich procedur związanych z zarządzaniem miastem oraz skuteczna aktywizacja obywateli, których ambicją były działania na rzecz zmian we własnym mieście?

Celem artykułu jest przedstawienie genezy i działalności ruchów miejskich typu smart city na Podkarpaciu, a także weryfikacja następujących hipotez badawczych: 1) Rzeszów Smart City oraz Mielec Smart City to przykłady nowoczesnej inicjatywy społecznej; 2) ruchy te stanowią przykład działalności partyjnej pod zmienionym szyldem. Do ich weryfikacji posłużono się trzema pytaniami badawczymi: 1) w jakich okolicznościach doszło do utworzenia wymienionych ruchów miejskich?; 2) jakie były główne cele związane z zainicjowaniem działalności ruchów typu smart cities?; 3) czy idea utworzenia tych ruchów miała związek z modernizacją miasta czy też z motywami związanymi z budową zaplecza politycznego na okoliczność wyborów samorządowych? Podstawę do zaprezentowania niniejszych rozważań stanowiły internetowe źródła dotyczące omawianych ruchów oraz materiały o charakterze publicystycznym.

8 K. Życzkowska, Informacyjna warstwa przestrzeni komercyjnej-smart city a wizerunek miasta, Zeszyty Naukowe Uniwersytetu Szczecińskiego, Studia Informatica nr 29, red. A. Smalec, Wydawnictwo Naukowe Uniwersytetu Szczecińskiego, Szczecin 2012, s. 170.

$9 \quad$ Szerzej na temat koncepcji smart cities zob. D. Sikora-Fernandes, Smart city - nowy trend w rozwoju miast czy moda na kolejnq etykietkę?, „Innowacja i Rozwój” 2014, nr 4, s. 4-6; Raport przyszłość miast - miasta przyszłości, http://mttp.pl/pobieranie/RaportMiastoPrzyszlosci. pdf (3.09.2015). 


\section{Rzeszów Smart City}

Szerszym tłem związanym z powstaniem ruchu miejskiego w Rzeszowie było zainicjowanie działalności komitetu akademicko-samorządowego Prawa i Sprawiedliwości (PiS) pod koniec maja 2015 roku $^{10}$. Komitet ten, według zamysłu jego twórcy - Tomasza Poręby, posła do Parlamentu Europejskiego VII i VIII kadencji - stanowił po pierwsze, kontynuację działalności Podkarpackiej Akademii Samorządności im. Grażyny Gęsickiej ${ }^{11}$; po drugie, skupiał osoby związane ze środowiskiem akademickim i samorządowym; po trzecie, organizował liczne spotkania z politykami, w tym również z przedstawicielami jednostek samorządu terytorialnego, środowisk akademickich oraz mieszkańcami Rzeszowa i województwa podkarpackiego. Tak powołany komitet stawiał sobie za główny cel stworzenie koncepcji dotyczącej rozwoju Rzeszowa i Podkarpacia, a także, jak tłumaczył T. Poręba: ,przełamanie niemocy w wyborach na prezydenta Rzeszowa, w których wciąż, pomimo dużego poparcia w województwie, kandydat PiS nie jest w stanie zaistnieć osiągając często wynik poniżej wszelkich oczekiwań" ${ }^{\prime 2}$. Wspomniana wyżej niemoc polityków PiS oraz przedstawicieli innych środowisk politycznych podyktowana była stosunkowo wysokim poparciem, którym od 2002 roku cieszył się urzędujący prezydenta miasta Rzeszowa,

10 Formalne utworzenie komitetu nastąpiło w trakcie posiedzenia Komitetu Politycznego PiS. Podstawę do jego utworzenia stanowił artykuł 19 par. 10 statutu PiS, w którym czytamy, iż do kompetencji tegoż komitetu należy „tworzenie i znoszenie jednostek organizacyjnych, przy pomocy których kieruje bieżącą działalnością PiS, w tym struktur terenowych PiS, nadawanie tym jednostkom oraz strukturom regulaminu organizacyjnego, a także powoływanie i odwoływanie osób stojących na czele tych jednostek i struktur", Statut Prawa i Sprawiedliwości, Warszawa 2013, s. 17.

11 Komitet ten zainicjował działalność na początku lipca 2014 r. Jego twórcą był marszałek województwa podkarpackiego, Władysław Ortyl. Należy jednak podkreślić, że komitet ten stanowi kontynuację działań Podkarpackiej Akademii Samorządności (PAS), inicjatywę zapoczątkowaną przed wyborami samorządowymi w 2010 r. przez Grażynę Gęsicką (Minister Rozwoju Regionalnego), W. Ortyla (ówczesnego senatora RP), Stanisława Ożoga (posła na Sejm RP) przy jednoczesnym wsparciu Tomasza Poręby (posła do Parlamentu Europejskiego). Decyzję o utworzeniu PAS podjął Zarząd PiS okręgu nr 23 27.11.2009 r. Głównym celem przyświecającym tej inicjatywie było przygotowanie osób i kandydatów zamierzających startować z listy PiS w wyborach samorządowych w 2010 r. pod kątem poznania zasad związanych z funkcjonowaniem jednostek samorządu terytorialnego i dobrego rządzenia w interesie społeczności lokalnych. Inauguracja PAS nastąpiła 10.08.2010 r. w Ropczycach. Od tego momentu PAS funkcjonowała w różnej formule. Najczęściej przybierała ona formę konferencji, debat i forum dotyczących problemów mieszkańców i regionu. Model ten powielono również w przypadku PAS im. G. Gęsickiej.

12 PiS powołat nowy komitet. Ma przyciagnać młodych, http://rzeszow.gazeta.pl/rzeszow/1,34962,17999537,PiS_powolal_nowy_komitet_Ma_przyciagnac_mlodych.html (4.09.2015). 
Tadeusz Ferenc ${ }^{13}$. Ten stan rzeczy powodował, że od 2010 roku liderzy Polskiego Stronnictwa Ludowego (PSL), a od 2014 roku także Platformy Obywatelskiej (PO) zaprzestali praktyki wystawiania własnych kandydatów w walce o prezydenturę Rzeszowa, ograniczając się do przekazania oficjalnego poparcia udzielonego T. Ferencowi ${ }^{14}$. Powodowało to, że nawet najbardziej merytoryczny i rozpoznawalny w regionie kandydat PiS nie był w stanie uzyskać wyniku wyborczego zbliżonego do tego, który osiągał obecny prezydent miasta.

Powołanie komitetu akademicko-samorządowego PiS niosło z sobą jeszcze jedno ważne zadanie, kierowane głównie do sympatyków tego ugrupowania. Komitet miał czynnie uczestniczyć w życiu partii, wspierać jego miejskie i wojewódzkie struktury zwłaszcza przez ich rozbudowę i napływ nowych członków, a także stanowić „kuźnię” pomysłów ludzi młodych i ambitnych, którym zależało na rozwoju Rzeszowa i województwa podkarpackiego. Szefem komitetu został najbliższy współpracownik T. Poręby, 28-letni Marcin Fijołek, przewodniczący Forum Młodych PiS okręgu nr 23, a także przewodniczący klubu radnych PiS w Radzie Miasta Rzeszowa ${ }^{15}$. Konkurenci polityczni ocenili powołanie tej inicjatywy jako zapowiedź przejęcia władzy w rzeszowskim ratuszu przez PiS w 2018 roku, natomiast w kuluarach tej partii od razu pojawiły się nazwiska dwóch potencjalnych kandydatów, którzy z ramienia partii mogliby przystąpić do rywalizacji w wyborach bezpośrednich na urząd prezydenta Rzeszowa. Byli to Wojciech Buczak, były szef rzeszowskiej „Solidarności” oraz M. Fijołek. O ile pierwszy z nich wyraził się pozytywnie na temat zgłoszonej propozycji, o tyle drugi nie komentował tego w ogóle.

13 Tadeusz Ferenc, ur. 10.02.1940 r. w Rzeszowie, polski polityk, poseł na Sejm IV kadencji w latach 2001-2002 wybrany z ramienia SLD w okręgu rzeszowskim. W 2002 r. został wybrany na prezydenta Rzeszowa uzyskując 51,63\% głosów poparcia (w I turze głosowania zdobył 44,39\% głosów), w 2006 r. uzyskał reelekcję z poparciem 76,59\%, a w 2010 r. ponownie wygrał w I turze głosowania zdobywając 53,25\% wszystkich głosów. W 2014 r. został po raz czwarty wybrany na prezydenta miasta uzyskując 66,30\% wszystkich głosów. W 2007 r. zgłosił pomysł ubiegania się o mandat senatora, jednak po dwóch tygodniach od ogłoszenia decyzji wycofał swój udział z startu w wyborach. O mandat ten bezskutecznie ubiegał się w 2011 r. z ramienia własnego komitetu wyborczego „Rozwój Podkarpacia”. W 2015 r. ponownie zapowiedział udział w rywalizacji politycznej o miejsce w Senacie.

14 Ł. Solski, PSL poparło Tadeusza Ferenca $w$ walce o fotel prezydenta Rzeszowa, http://rzeszow.naszemiasto.pl/artykul/psl-poparlo-tadeusza-ferenca-w-walce-o-fotel-prezydenta,618134,art,t,id,tm.html (4.09.2015); PO poparla Tadeusza Ferenca $w$ wyborach na prezydenta Rzeszowa, http://rzeszow-news.pl/poparla-tadeusza-ferenca-wyborach-prezydenta-rzeszowa (4.09.2015).

15 A. Rogowski, PiS chce przyciagnać młodych ludzi, http://supernowosci24.pl/pis-chce -przyciagnac-mlodych-ludzi/ (5.09.2015). 
Inicjatywa przejęcia władzy przez PiS spotkała się z natychmiastową reakcją Konrada Fijołka, wiceprzewodniczącego Rady Miasta, członka klubu radnych Rozwój Rzeszowa i sekretarza Rady Wojewódzkiej Sojuszu Lewicy Demokratycznej (SLD), który również pod koniec maja 2015 roku powołał Dynamiczny Ruch Miejski (DRM), stanowiący kontrpropozycję dla komitetu akademicko-samorządowego $\mathrm{PiS}^{16}$. O jego powstaniu poinformowano na portalu społecznościowy Facebook przez utworzenie inicjatywy pod wymowną nazwą „Nie oddamy Rzeszowa w ręce PiS”, by sprawdzić jaki będzie odzew społeczny. W stosunkowo szybkim czasie odpowiedziało na nią ok. 130 osób, które zadeklarowały udział w nowym przedsięwzięciu. Ważnym aspektem DRM podkreślanym w licznych wywiadach udzielanych przez K. Fijołka lokalnym mediom było to, że miał on ponadpartyjny charakter oraz miał działać wyłącznie na rzecz rozwoju Rzeszowa, a nie żadnej partii politycznej ${ }^{17}$.

Sama oferta DRM skierowana była głównie do młodych ludzi, 20-, 30i 40-letnich, nowoczesnych, zdroworozsądkowych, pochodzących z różnych środowisk, społeczników, członków Rzeszowskiego Budżetu Obywatelskiego (RBO), działaczy osiedlowych i stowarzyszeń. Już wówczas padła wstępna deklaracja ze strony K. Fijołka, który stwierdził: ,jeśli udałoby się nam stworzyć fajny ruch, ruch młodych ludzi, który nabrałby odpowiedniej siły i przekonania, że może wpływać na losy miasta, to byłoby dobrze, żeby to środowisko miało lidera, który ubiegałby się o prezydenturę. Na pewno to rozważam, ale to wszystko zależy od ludzi, którzy będą o tym decydować"18.

Proces organizacyjny ruchu miejskiego trwał do 11 czerwca 2015 roku, kiedy to zorganizowano plenerową konferencję nad Wisłokiem ${ }^{19}$. Jej organizator poinformował wówczas, że zrezygnowano z wysuwania nieprzychylnych pod adresem PiS akcji typu „anty” czy „przeciwko” na rzecz uczynienia „kroku do przodu” i „czegoś pozytywnego”. Organizatorom ruchu chodziło przede wszystkim o zainicjowanie działań zmierzających do unowocześnienia Rzeszowa. Przedstawiono wówczas oficjalną nazwę tworzonej inicjatywy, którą określono jako Rzeszów Smart City (RSC). Jak wspomnieli uczestnicy tego spotkania,

16 Była to nazwa robocza przyjęta na potrzeby uruchomionej inicjatywy na Facebooku. Oficjalna nazwa została ogłoszona 11.06.2015 r.

17 M. Bujara, Młodzi staja do walki o Rzeszów, http://m.rzeszow.gazeta.pl/rzeszow/1,106519,18027274,Mlodzi_staja_do_walki_o_Rzeszow.html (5.09.2015).

18 Nowy ruch w Rzeszowie. ,Nie oddamy miasta $w$ ręce PiS”, http://rzeszow-news.pl/nowy -ruch-w-rzeszowie-nie-oddamy-miasta-w-rece-pis (5.09.2015).

19 Rzeka w południowo-wschodniej Polsce stanowiąca lewy dopływ Sanu o łącznej długości $220 \mathrm{~km}$ 
zmiana nazwy miała pokazać, że ruch miejski był otwarty na ludzi o różnych poglądach, którym zależało na inteligentnym i mądrym rozwoju miasta ${ }^{20}$. Zasadniczym celem, który towarzyszył wspomnianemu spotkaniu było również zaprezentowanie celów programowych RSC (zob. tab. 1). W konferencji uczestniczyło łącznie ok. 20 osób. Oprócz K. Fijołka, udział w niej wzięli m.in. Arkadiusz Leśniak-Moczuk (inicjator budowy toru do wyścigów samochodowych), Anna Skiba (bizneswoman), Mikołaj Fischer (architekt), Mateusz Hanf (szef rady osiedla Śródmieście Południe), Mateusz Maciejczyk (działacz społeczny) i Sylwia Bezak (licealistka) ${ }^{21}$.

Inicjatywa powstania ruchu miejskiego oraz deklaracja ubiegania się K. Fijołka o urząd prezydenta miasta w 2018 roku spotkała się z ciepłym przyjęciem w gronie klubu radnych Rozwój Rzeszowa oraz w samym SLD. Politycznego „błogosławieństwa” nowemu ruchowi oraz K. Fijołkowi jako kandydatowi na prezydenta miasta udzielił T. Ferenc, który miesiąc później publicznie ogłosił deklarację ubiegania się o mandat senatora w wyborach parlamentarnych w 2015 roku. W związku z powyższym T. Ferenc publicznie poparł Zdzisława Gawlika, polityka PO, sekretarza stanu w Ministerstwie Skarbu Państwa, podkreślając jego kwalifikacje. Stwierdził on: „chcę, żeby moje miejsce zajął Zdzisław Gawlik. Znamy się od lat, to mądry, wykształcony człowiek. Jestem przekonany, że pan Gawlik dobrze pokieruje miastem"22. Powyższa nobilitacja nie byłaby zaskoczeniem, gdyby nie to, że Z. Gawlik nie wyraził deklaracji startu w wyborach na prezydenta miasta. Wobec tego stanu rzeczy odniósł się K. Fijołek, który stwierdził: „To decyzja prezydenta, nie zamierzam z nią dyskutować. Ja założyłem ruch Rzeszów Smart City, który zyskuje dużą popularność wśród ludzi młodych, energicznych i pełnych pomysłów. Mam nadzieję, że przełoży się to na wynik wyborów. Nie mam żalu do prezydenta, że to nie mnie namaścił na swojego następcę"23.

20 „Rzeszów Smart City”. Nowy pomysł radnych Rozwoju Rzeszowa, www.radio.rzeszow.pl/informacje/item/38013-rzeszow-smart-city-nowy-pomysl-radnych-rozwoju-rzeszowa (6.08.2015).

$21 \quad$ A. Gernand, Narysujmy wspólnie Rzeszów 2030. Nowy ruch w mieście, http://m.rzeszow.gazeta.pl/rzeszow/1,106519,18103880,Narysujmy_wspolnie_Rzeszow_2030_Nowy_ruch_w_miescie.html (6.09.2015).

${ }_{22}$ Tadeusz Ferenc chce być w Senacie. Jest oficjalna decyzja, http://rzeszow-news.pl/tadeusz-ferenc-chce-byc-w-senacie-jest-oficjalna-decyzja/ (6.09.2015).

23 B. Gubernat, Tadeusz Ferenc chce do Senatu. Komu odda Rzeszów?, http://www.nowiny24.pl/apps/pbcs.dll/article?AID=/20150720/RZESZOW/150719712 (7.09.2015). 
Tabela 1. Cele programowe ruchów miejskich smart cities na Podkarpaciu

\begin{tabular}{|c|c|c|}
\hline \multirow{2}{*}{ Cele programowe } & Rzeszów Smart City (RSC) & Mielec Smart City (MSC) \\
\hline & \multicolumn{2}{|c|}{ przykłady proponowanych działań } \\
\hline 1 & 2 & 3 \\
\hline $\begin{array}{l}\text { Inteligentny rozwój } \\
\text { gospodarczy } \\
\text { polega na wspieraniu sektora } \\
\text { badań i rozwoju dającego } \\
\text { trwały rozwój gospodarczy; } \\
\text { jego celem jest wspieranie } \\
\text { rozwoju mikro i małych firm } \\
\text { stanowiących 90\% potencjału } \\
\text { przedsiębiorczości, ułatwianie } \\
\text { startu nowym firmom, prze- } \\
\text { pływ towarów, usług i wiedzy } \\
\text { na poziomie miasta oraz } \\
\text { między miastami } \\
\end{array}$ & $\begin{array}{l}\text { - } \text { utworzenie Inkubatora } \\
\text { Startujących Przedsiębiorstw } \\
\text { - powołanie Fundacji Wsparcia } \\
\text { Start-Upów z udziałem kapitału } \\
\text { lokalnego i polonijnego } \\
\text { - } \text { wsparcie e-biznesu }\end{array}$ & $\begin{aligned} \text { - } & \text { utworzenie punktu wsparcia przed- } \\
& \text { siębiorczości } \\
\text { - } & \text { wdrożenie nowoczesnych tech- } \\
& \text { nologii umożliwiających rozwój } \\
& \text { miasta } \\
\text { - } & \text { stworzenie nowych miejsc } \\
& \text { pracy dzięki wsparciu lokalnych } \\
& \text { firm z jednoczesnym wyko- } \\
& \text { rzystaniem Mieleckiego Parku } \\
& \text { Przemysłowego i Specjalnej Strefy } \\
& \text { Ekonomicznej } \\
\text { - } & \text { umacnianie strefy ekonomicznej } \\
\text { - } & \text { modernizacja mieleckiego lotniska }\end{aligned}$ \\
\hline \begin{tabular}{|l} 
Inteligentne zarządzanie \\
polega na transparentnej \\
wymianie informacji między \\
mieszkańcami, a także mię- \\
dzy miastem i innymi jednost- \\
kami funkcjonującymi na \\
jego terenie np. centralnymi, \\
ratowniczymi, czy policją \\
\end{tabular} & $\begin{array}{l}\text { - wprowadzenie systemu e-informa- } \\
\text { cji „Bicon system” } \\
\text { - wykorzystanie najnowszych } \\
\text { aplikacji informatycznych w sku- } \\
\text { tecznym zarządzaniu miastem }\end{array}$ & $\begin{array}{l}\text { - } \text { wdrożenie alertownika } \\
\text { - } \text { uruchomienie contact center } \\
\text { - realizacja inicjatyw społecznych } \\
\text { i obywatelskich. }\end{array}$ \\
\hline $\begin{array}{l}\text { Inteligentna mobilnośćl } \\
\text { transport } \\
\text { polega na tworzeniu efek- } \\
\text { tywnych, bezpiecznych } \\
\text { i sprawnie powiązanych sys- } \\
\text { temach zarządzania logistyką, } \\
\text { transportem, komunikacją } \\
\text { publiczną, ruchem rowero- } \\
\text { wym oraz parkowaniem }\end{array}$ & $\begin{aligned} \text { - } & \text { wprowadzenie wielopoziomowego } \\
& \text { układu skrzyżowań komunika- } \\
& \text { cyjnych } \\
\text { - } & \text { realizacja II etapu Inteligentnego } \\
& \text { Systemu Równoważnia Transportu } \\
\text { - } & \text { wspieranie alternatywnych środ- } \\
& \text { ków transportu }\end{aligned}$ & $\begin{aligned} \text { - } & \text { wprowadzenie sekundników } \\
\text { - } & \text { poprawa jakości nawierzchni dróg } \\
& \text { i chodników } \\
\text { - } & \text { rozbudowa terenów rekreacyjnych } \\
& \text { wokół Mielca } \\
\text { - } & \text { zwiększenie wykorzystania } \\
& \text { transportu publicznego poprzez } \\
& \text { zwiększenie dostępności do linii } \\
& \text { autobusowych }\end{aligned}$ \\
\hline $\begin{array}{l}\text { Inteligentna ekologia } \\
\text { polega na promocji eko- } \\
\text {-postaw, systematycznej } \\
\text { rozbudowie zieleni miejskiej, } \\
\text { poszerzeniu oferty rekreacyj- } \\
\text { nej dla mieszkańców }\end{array}$ & $\begin{array}{l}\text { - wprowadzenie inteligentnych } \\
\text { liczników i urządzeń wspomagają- } \\
\text { cych ograniczenie zużycia energii } \\
\text { w domach i mieszkaniach } \\
\text { - } \text { wprowadzenie inteligentnych } \\
\quad \text { systemów oświetleniowych } \\
\text { - implementacja odnawialnych } \\
\text { źródeł energii } \\
\text { - } \text { wykończenie systemu ścieżek re- } \\
\text { kreacyjnych wzdłuż rzeki Wisłok } \\
\text { - } \text { budowa promenady nad } \\
\text { Wisłokiem }\end{array}$ & $\begin{aligned} \text { - } & \text { rewitalizacja wysypiska } \\
\text { - } & \text { redukcja szkodliwych zanieczysz- } \\
& \text { czeń } \\
\text { - } & \text { budowa parku historycznego }\end{aligned}$ \\
\hline
\end{tabular}




\begin{tabular}{|c|c|c|}
\hline 1 & 2 & 3 \\
\hline $\begin{array}{l}\text { Inteligentna edukacja } \\
\text { polega na promowaniu life } \\
\text { long learning (kształcenia } \\
\text { ustawicznego), a także za- } \\
\text { pewnieniu dostępu do szkoleń } \\
\text { i edukacji poprzez nowo- } \\
\text { czesne systemy nauczania } \\
\text { z wykorzystaniem technologii } \\
\text { komunikacyjnych; dodatkowo } \\
\text { inteligentna edukacja stanowi } \\
\text { wparcie kreatywności i po- } \\
\text { tencjału ludzkiego, jej celem } \\
\text { jest umożliwienie aktyw- } \\
\text { nego udziału mieszkańców } \\
\text { miasta w życiu społeczności } \\
\text { miejskiej }\end{array}$ & $\begin{array}{l}\text { - } \text { finansowanie przedmiotów ekono- } \\
\text { micznych } \\
\text { - utworzenie szkół prowadzonych } \\
\text { wyłącznie w języku angielskim } \\
\text { - utworzenie szkoły średniej przy- } \\
\text { gotowującej do matury międzyna- } \\
\text { rodowej }\end{array}$ & $\begin{array}{l}\text { - rozwój edukacji dla rozwoju dzieci } \\
\text { i rodziców } \\
\text { - ograniczenie odpływu młodej } \\
\text { kadry przez stworzenie dostępu do } \\
\text { szkół wyższych }\end{array}$ \\
\hline $\begin{array}{l}\text { Inteligentny styl życia } \\
\text { polega na umożliwieniu } \\
\text { mieszkańcom dalszego pod- } \\
\text { noszenia jakości swego życia }\end{array}$ & $\begin{aligned} & \text { - } \text { opracowanie specjalnej oferty dla } \\
& \text { studentów } \\
& \text { - } \text { zwiększenie puli środków } \\
& \text { przeznaczonych w Rzeszowskim } \\
& \text { Budżecie Obywatelskim na } \\
& \text { projekty miękkie (organizację } \\
& \text { nowych wydarzeń kulturalnych) } \\
& \text { - } \text { organizowanie jednego nowego } \\
& \text { wydarzenia w stylu europejskim } \\
& \text { (festiwal lub konkurs) } \\
& \text { - } \text { wdrożenie systemu e-informacji } \\
& \text { medycznej dla mieszkańców } \\
& \text { Rzeszowa }\end{aligned}$ & $\begin{array}{l}\text { - } \text { wsparcie dla świetlic profilaktycz- } \\
\text { no-wychowawczych; } \\
\text { - } \text { profilaktyka zdrowia i świadome } \\
\text { żywienie } \\
\text { - } \text { aktywna kobieta - świadoma } \\
\text { i zdrowa rodzina } \\
\text { - rozbudowa miasteczka studenc- } \\
\text { kiego } \\
\text { - rozbudowa i uatrakcyjnienie wido- } \\
\text { ków plenerowych wokół Mielca } \\
\text { - } \text { wsparcie funkcjonowania szpitala } \\
\text { powiatowego }\end{array}$ \\
\hline Miasto i jego infrastruktura & $\begin{array}{l}\text { - } \text { rozszerzenie granic miasta pod } \\
\text { nowe inwestycje } \\
\text { - } \text { pełna informatyzacja miasta, } \\
\text { w tym także przystanków autobu- } \\
\text { sowych } \\
\text { - } \text { wprowadzenie systemu inteligent- } \\
\text { nych tablic na sygnalizacji świetl- } \\
\text { nej informującej o potencjalnych } \\
\text { utrudnieniach w ruchu drogowym }\end{array}$ & $\begin{aligned} \text { - } & \text { rozszerzenie granic miasta pod } \\
& \text { nowe inwestycje } \\
\text { - } & \text { wypracowanie skutecznej strategii } \\
& \text { promocji miasta } \\
\text { - } & \text { promocja miasta przez kulturę } \\
\text { - } & \text { zbudowanie drugiego mostu na } \\
& \text { Wisłoce }\end{aligned}$ \\
\hline
\end{tabular}

Źródło: opracowanie własne na podstawie www.facebook.com/rzeszowsmartcity?fref=ts; www.facebook.com/Mielec-Smart-City-1596226260666279/timeline (8-10.09.2015).

Wśród politycznych konkurentów K. Fijołka pojawiły się negatywne opinie świadczące o budowie jego zaplecza politycznego bez partyjnej etykiety. Przypominano, że w przeszłości w Rzeszowie zdarzyły się wyborcze inicjatywy podkreślające brak partyjnych konotacji. Ten stan rzeczy trafnie określiła Ewa Nalewajko stwierdzając, ,iż zacieranie przynależności partyjnych jest wyrazem indywidualnych strategii działaczy, silniej zorientowanych na politykę lokalną niż na ponadlokalne struktury partyjne”. Zauważała również, że ,„partyjne szyldy 
nie są lubiane zarówno przez wyborców, jak i przez bezpartyjnych działaczy samorządowych. Budzą w nich dystans i nieufność"24. Częściowym potwierdzeniem tych słów może być refleksja przedstawiona przez K. Fijołka, twórcę RSC, który stwierdził: „spojrzałem na siebie, na to, co robiłem przez ostatnie lata i zastanowiłem się, jaki ze mnie polityk? W jakich istotnych politycznych wydarzeniach uczestniczyłem? Tak naprawdę od 13 lat jestem samorządowcem. Spójrzcie na prezydenta Ferenca, który ma taką, a nie inną proweniencję polityczną. Tak naprawdę sprawując urząd nigdy, na to nie patrzył, zawsze kierował się i kieruje interesem miasta. I wpoił nam, że ta łatka polityczna nie ma znaczenia"25.

Z powyższą argumentacją nie zgodziłby się Maciej Drzonek, który zauważył trafnie, że bardzo często „aktor partyjny pozoruje bezpartyjność”26. Zarzut ten był najczęściej wysuwany przez przeciwników tak K. Fijołka, jak i powołanego przez niego ruchu miejskiego. Od momentu publicznego ogłoszenia nazwy ruchu, deklaracji K. Fijołka o zamiarze ubiegania się o urząd prezydenta i decyzji T. Ferenca dotyczącej startu w nadchodzących wyborach, RCS ograniczył swoją bieżącą działalność wyłącznie do publikowania na stronie internetowej informacji o potencjalnych projektach, które wpisywały się w koncepcję smart cities. Było to m.in. zaproszenie do nadsyłania oceny stanu rzeczywistego i wizji przyszłości Rzeszowa. Zebrane w ten sposób wnioski miały zostać wykorzystane w trakcie prac nad Strategią Rozwoju Miasta Rzeszowa do 2030 roku (w myśl głównego hasła ruchu - „Zbudujmy razem Rzeszów 2030”); postulat stworzenia w mieście smart dogów - specjalnych budek przeznaczonych na odpady dla zwierząt; czy inicjatywy Dron Show Rzeszów 2015 Prolog (smart drony), którą zorganizowano 11 września 2015 roku w Rzeszowie. Jej celem było promowanie zasad bezpieczeństwa podczas użytkowania dronów (statków bezzałogowych). Docelowym działaniem RSM było zwołanie kongresu społeczników, działaczy miejskich i przedstawicieli organizacji pozarządowych, którą zaplanowano na październik 2015 roku.

Do ostatecznej organizacji kongresu społeczników nie doszło głównie wskutek zainicjowania przez K. Fijołka oraz pracowników z Instytutu Nauk o Polityce Uniwersytetu Rzeszowskiego cyklu ośmiu konferencji naukowych poświęconych

24 E. Nalewajko, Powiatowe partie polityczne, w: Powiatowa elita polityczna, red. J. Wasilewski, Warszawa 2006, s. 192.

25 A. Gernand, Narysujmy wspólnie Rzeszów 2030..., http://m.rzeszow.gazeta.pl/rzeszow/1,106519,18103880,Narysujmy_wspolnie_Rzeszow_2030_Nowy_ruch_w_miescie.html, (data dostępu: 11.09.2015).

26 M. Drzonek, Reelekcje prezydentów miast w wyborach bezpośrednich w Polsce, Kraków 2013, s. 149. 
smart cities. Tematami, które stały się przedmiotem ożywionych obrad były: 1) idea inteligentnych miast; 2) smart governance - planowanie strategiczne i zarządzanie i zarządzanie inteligentnymi miastami; 3) smart design - wyzwania urbanistyczne i architektoniczne; 4) smart technology - rozwiązania informacyjno-komunikacyjne; 5) smart citizens - aktywność obywatelska i partycypacja publiczna; 6) smart tourism - turystyka i rekreacja; 7) smart environment - ochrona środowiska i zasobów naturalnych; 8) smart life - jakość życia. Warto jednak podkreślić, że zorganizowane konferencje medialnie przyczyniły się nie tylko do wzmocnienia, ale do jeszcze większego wypromowania osoby K. Fijołka oraz RSC na lokalnej scenie politycznej aniżeli wcześniej, co stanowiło swoiste zbijanie kapitału społecznego.

Drugim ważnym argumentem, który przemawiał za brakiem zorganizowania wspomnianego już kongresu była przegrana T. Ferenca w wyborach na senatora, która uniemożliwiła rzeczywiste powołanie komitetu wyborczego. Tylko w takiej sytuacji ruch miejski stanowiłby zaplecze polityczne K. Fijołka umożliwiające mu udział w bezpośrednich wyborach na prezydenta miasta bez konieczności promowania partyjnej etykiety. Dopiero wybory samorządowe w 2018 roku umożliwią zweryfikowanie na ile RSC stanowi autentyczny ruch miejski, a na ile jego działalność nastawiona jest na cele polityczne.

\section{Mielec Smart City}

Powstanie ruchu miejskiego Mielec Smart City (MSC) formalnie nastąpiło 18 czerwca 2015 roku. Jego inicjatorem był 39-letni Daniel Kozdęba, członek SLD, wybrany w 2014 roku na urząd prezydenta Mielca z ramienia komitetu wyborczego Razem dla Ziemi Mieleckiej ${ }^{27}$. W jego programie wyborczym szczególny nacisk został położony m.in. na „sukcesywne wprowadzenie do miasta odnawialnych źródel energii [wyróżnienie - D.S.] dostępnych dla mieszkańców przez wdrażanie koncepcji inteligentnego miasta (smart city)"228. Skutecznym narzędziem służącym do realizacji powyższego założenia było powołanie ruchu miejskiego MSC, którego podstawowym i zarazem najważniejszym fundamentem mieli być mieszkańcy Mielca chcący pracować na rzecz nowoczesnego

27 Daniel Kozdęba, ur. się 12.11.1976 r. w Mielcu. Członek SLD. W latach 2002-2006 oraz 2006-2010 był radym powiatu mieleckiego. W wyborach samorządowych w 2014 r. zdobył 61,19\% głosów pokonując tym samym ówczesnego prezydenta Mielca Janusza Chodorowskiego, wybranego na ten urząd w 1994 r.

28 Daniel Kozdęba. Kandydat na prezydenta Mielca oraz radnego powiatu, druk ulotny, s. 3 (w zbiorach autora). 
i inteligentnego miasta przy jednoczesnym wykorzystaniu nowoczesnych technologii.

Główny obszar aktywności komunikacyjnej nowego ruchu miejskiego dotyczył portalu społecznościowego Facebook, gdzie uruchomiono stronę internetową „Mielec Smart City”. Pojawiły się na niej oficjalne zaproszenia kierowane przez prezydenta miasta do „ludzi 20-, 30-, 40-letnich, zdroworozsądkowych, innowacyjnych, nowoczesnych, społeczników z różnych środowisk”. Dalej Kozdęba stwierdzał: „,zależy nam na tych, którzy angażują się w działalność różnych stowarzyszeń, działaczach osiedlowych. Zachęcamy również przedsiębiorców oraz ludzi, którzy wierzą, że Mielec może się rozwijać”29.

Oceniając tę inicjatywę Kozdęba konkludował: „chcę, aby ruch miejski Mielec Smart City nie miał partyjnego logo. Chciałbym, aby był to ruch, który ma na celu jednoczenie ludzi od lewa do prawa, którzy chcą działać na rzecz miasta Mielca i jego rozwoju. Poglądy nie mają znaczenia ważne jest, że chcesz rozwijać Mielec. My zapraszamy Cię do działania. Razem. Mielec jest i będzie i musi być miastem mieszkańców, którzy chcą rozwijać to miasto"30.

Zainicjowana na Facebooku akcja spotkała się z szybkim odzewem mieszkańców. Liczba zgłoszeń świadczących o chęci podjęcia działań na rzecz rozwoju Mielca zaowocowała w stosunkowo szybkim czasie uruchomieniem na wspomnianej stronie internetowej akcji dotyczącej popierania ruchu MSC. Polegało to na prezentowaniu zdjęć osób, które przyłączyły się do inicjatywy D. Kozdęby z jednoczesnym prezentowaniem napisu „Popieram Mielec Smart City”. Już 11 lipca 2015 roku zorganizowano plenerowe spotkanie w celu ustalenia programu ruchu miejskiego. Jego istotnym elementem była wzajemna chęć poznania oraz szeroka wymiana myśli koncentrująca się wokół koncepcji i planów rozwoju miasta (zob. tab. 1). Uczestniczyli w nim, oprócz D. Kozdęby, m.in.: Michał Tomczyk, Bartosz Madejczyk, Sławomir Kopek oraz przedstawiciele zawiązanej na Facebooku grupy „Aktywne Kobiety Mielec i nie tylko”. Spotkanie zgromadziło łącznie ok. 30 osób.

Wymiernym rezultatem wdrażania w Mielcu idei smart city było uruchomienie pod koniec lipca 2015 roku Alertownika, czyli aplikacji służącej do kontaktowania się mieszkańców miasta z urzędnikami. Według prezydenta Mielca stanowiła ona doskonałe źródło informacji o tym, czego oczekiwali mieszkańcy i tego, co wymagało szybkiej reakcji magistratu, np. poprawy infrastruktury,

29 Ruch miejski Mielec Smart City Daniela Kozdęby, http://rmi24.pl/2015/06/20/ruch-miejski-mielec-smart-city-daniela-kozdeby/ (11.09.2015).

30 Ibidem. 
wymiany koszy na śmieci czy uszkodzonej kostki brukowej na chodniku. Jak zauważył D. Kozdęba: „bardzo istotne dla nas jest to, że dzięki temu systemowi informacje od mieszkańców będziemy otrzymywać bardzo szybko, a to pozwoli nam na reakcję. Aplikacja ta, to także możliwość wdrażania idei Smart City, czyli miasta, które cały czas dzieli się informacją płynącą w obu kierunkach"31.

Zasada działania Alertownika była stosunkowo prosta. Jej odbiorcami byli wyłącznie użytkownicy smartfonów. W przypadku zgłoszenia konkretnej uwagi, wiadomość trafiała do administratora, ten kierował ją do odpowiedniego wydziału, który odpowiadał za dany problem. Dzięki temu zgłaszający mógł na bieżąco śledzić status swojego zgłoszenia. Oprócz tego Alertownik oferował mieszkańcom Mielca przekazywanie krótkich powiadomień tekstowych, np. o korkach ulicznych, nadchodzących burzach.

W drugiej połowie sierpnia 2015 roku na stronie internetowej MSC zamieszczono informację na temat Budżetu Obywatelskiego, do którego w Mielcu zgłoszono pięć projektów. Były to: smart park smoczka (inwestycja budowy parku oszacowana na 265 tys. zł); smart lodowisko (koszt realizacji 75 tys. zł); smart drogi - sekundniki pokazujące ile czasu zostało do zmiany sygnalizacji ruchu (80 tys. zł); smart plaża, siatkówka, kajaki, Wisłoka (zakładające rozbudowę i uatrakcyjnienie miejsc plenerowych wokół Mielca, służących przede wszystkim do relaksu, odpoczynku oraz rekreacji i sportu - koszt realizacji ok. 180 tys. zł) oraz smart edukacja, ścieżka lotnika i park leśny - inwestycja wyceniona na 80 tys. $z^{32}$. Celem zaprezentowania wyżej wymienionych propozycji było zaktywizowanie mieszkańców Mielca do zbierania podpisów pod najciekawszymi $\mathrm{z}$ ich punktu widzenia inwestycjami ${ }^{33}$.

Warto jednak zauważyć, że działalność MSC zasadniczo koncentrowała się na sferze wirtualnej. Ruch ten integrował sympatyków tylko na okoliczność organizowanych inicjatyw o charakterze miejskim. Grupował ludzi, którym bliska

31 Mielec chce być smart, działa już aplikacja do kontaktu z urzędnikami, www.samorzad. lex.pl/czytaj/-/artykul/mielec-chce-byc-smart-dziala-juz-aplikacja-do-kontaktu-z-urzednikami (11.09.2015).

32 Ostatnia z wymienionych propozycji Mieleckiego Budżetu Obywatelskiego dotyczyła budowy parku historycznego, w zbiorach którego znaleźć się miało 20 modeli samolotów, które niegdyś były lub obecnie są produkowane w Mielcu. Celem tej wystawy była edukacja mieszkańców i turystów w zakresie technologii lotniczej.

33 Docelowym rozwiązaniem służącym wszystkim mieszkańcom Mielca będzie uruchomienie specjalnego contact center, stanowiącego rozwinięcie koncepcji call center, którego głównym narzędziem umożliwiającym kontakt mieszkańców z magistratem będzie telefon stacjonarny. Prace nad tą inicjatywą jeszcze trwają. Por. D. Szczepański, Wywiad z prezydentem Mielca Danielem Kozdębą, Mielec 24.08.2015 (zapis rozmowy w posiadaniu autora). 
była koncepcja miasta rozwijającego się opartego na nowoczesnych technologiach. Formuła ponadpartyjnego charakteru MSC okazała się trafnym zamierzeniem D. Kozdęby, tym bardziej, że w żadnym z wywiadów oraz informacji zamieszczonych na stronie ruchu nie odwoływał się on do swoich lewicowych poglądów. Był on jedynie inicjatorem ruchu miejskiego, zaś głównymi jego aktorami byli mieszkańcy, którzy skutecznie mieli się przyczynić do szybkiego zmodernizowania miasta $\mathrm{w}$ stosunkowo krótkim czasie zawartą $\mathrm{w}$ haśle ruchu „Zbudujmy wspólnie Mielec 2030”34.

\section{Zakończenie}

Powołanie ruchów miejskich typu smart cities na Podkarpaciu przyczyniło się do zmobilizowania aktywności mieszkańców Rzeszowa i Mielca, a także wytyczyło przed liderami i członkami ruchu nowe kierunki działań zmierzające do unowocześnienia i zmodernizowania miasta opartego na nowych technologiach. Ważnym czynnikiem, który tu podkreślano była również zmiana świadomości obywatelskiej na rzecz estetyzacji miasta, polegającej m.in. na dbaniu o stan dróg, chodników, elewacji.

Postawione na początku pracy hipotezy badawcze wydają się zasadne z dwóch powodów. Po pierwsze, ruchy miejskie na Podkarpaciu stanowią przykład nowoczesnej inicjatywy społecznej, chociażby z powodów, które wymieniono wyżej. Oprócz tego warto wskazać na kluczowe przy działaniach tych ruchów mechanizmy angażowania sympatyków do działań zbiorowych, kwestię komunikacji i prezentacji samych przekazów komunikacyjnych, umożliwiających skuteczne mobilizowanie członków ruchu, wykorzystywanie internetu jako podstawowego narzędzia umożliwiającego dotarcie do szerokiego grona odbiorców, a także tworzenie więzi społecznych. Drugim ważnym kryterium jest wzrost znaczenia liderów, którzy dzięki zainicjowanej działalności ruchu miejskiego przyczynili się do aktywizacji postaw obywatelskich w ich środowiskach lokalnych.

Drugiej z postawionych hipotez badawczych nie potwierdzono głównie wskutek przegranej T. Ferenca w wyborach parlamentarnych w 2015 roku, co w znacznej mierze przyczyniło się do braku zainicjowania przez K. Fijołka przekształcenia RSC w twór o charakterze politycznym. Dzięki takiemu obrotowi spraw RSC zapoczątkował wraz z pracownikami Instytutu Nauk o Polityce Uniwersytetu Rzeszowskiego cykl konferencji naukowych dotyczących idei

34 Tamże. 
smart cities oraz praktycznych możliwości ich urzeczywistnienia. Kolejne wybory samorządowe w 2018 roku będą zatem stanowiły o tym, czy ruch miejski pozostanie w dalszym ciągu nowoczesną inicjatywą społeczną czy też przybierze formę ,,utajonej” działalności partyjnej pod zmienionym szyldem.

\section{Bibliografia}

Bujara Małgorzata, Młodzi stają do walki o Rzeszów, http://m.rzeszow.gazeta.pl/rzeszow/1,106519,18027274,Mlodzi_staja_do_walki_o_Rzeszow.html.

Daniel Kozdęba. Kandydat na prezydenta Mielca oraz radnego powiatu, druk ulotny.

Drzonek Maciej, Reelekcje prezydentów miast $w$ wyborach bezpośrednich $w$ Polsce, Kraków 2013.

Erbel Joanna, Ruchy miejskie jako nowa forma zaangażowania społecznego, http://wladzasadzenia.pl/2014/4/ruchy-miejskie-jako-nowa-forma-zaangazowania-spolecznego.pdf.

Gernand Artur, Narysujmy wspólnie Rzeszów 2030. Nowy ruch w mieście, http://m.rzeszow.gazeta.pl/rzeszow/1,106519,18103880,Narysujmy_wspolnie _ Rzeszow_2030_Nowy_ruch_w_miescie.html.

Gubernat Bartosz, Tadeusz Ferenc chce do Senatu. Komu odda Rzeszów?, www.nowiny24.pl/apps/pbcs.dll/article?AID=/20150720/RZESZOW/150719712.

Herbst Krzysztof, Ruchy nieformalne a kierunki rozwoju ekonomii społecznej. Rekomendacje dla polityk publicznych, Warszawa 2013.

Mielec chce być smart, działa już aplikacja do kontaktu z urzędnikami, www.samorzad. lex.pl/czytaj/-/artykul/mielec-chce-byc-smart-dziala-juz-aplikacja-do-kontaktu-z -urzednikami.

Nalewajko Ewa, Powiatowe partie polityczne, w: Powiatowa elita polityczna, red. Jacek Wasilewski, Warszawa 2006.

Nowy ruch w Rzeszowie. ,Nie oddamy miasta $w$ recce PiS”, http://rzeszow-news.pl/nowy -ruch-w-rzeszowie-nie-oddamy-miasta-w-rece-pis.

Olszewski Edward, Ruch społeczny, w: Encyklopedia politologii, t. 4, Myśl społeczna $i$ ruchy polityczne współczesnego świata, red. Marek Żmigrodzki, Zakamycze 2000 .

Paleczny Tadeusz, Nowe ruchy społeczne, Kraków 2010.

PiS powołał nowy komitet. Ma przyciagnać młodych, http://rzeszow.gazeta.pl/rzeszow/1,34962,17999537,PiS_powolal_nowy_komitet_Ma_przyciagnac_mlodych. html. 
Pluciński Przemysław, Im lepiej, tym gorzej albo widmo kryzysu miejskich ruchów spotecznych, „Ruch Prawniczy, Ekonomiczny i Socjologiczny” 2015, nr 1.

PO poparta Tadeusza Ferenca w wyborach na prezydenta Rzeszowa, http://rzeszownews.pl/poparla-tadeusza-ferenca-wyborach-prezydenta-rzeszowa.

Przybylski Wojciech, Problemy ruchów miejskich, w: Demokratyzacja miasta. Debaty Fundacji im. Stefana Batorego, www.batory.org.pl/upload/publikacje/DEBATY_ Demokratyzacja\%20miasta.pdf

Raport „Przyszłość miast - miasta przyszłości”, http://mttp.pl/pobieranie/RaportMiasto Przyszlosci.pdf.

Rogowski Arkadiusz, PiS chce przyciagnąć młodych ludzi, http://supernowosci24.pl/pis -chce-przyciagnac-mlodych-ludzi.

Ruch miejski Mielec Smart City Daniela Kozdęby, http://rmi24.pl/2015/06/20/ruch-miejski-mielec-smart-city-daniela-kozdeby.

„Rzeszów Smart City”. Nowy pomyst radnych Rozwoju Rzeszowa, www.radio.rzeszow.pl/informacje/item/38013-rzeszow-smart-city-nowy-pomysl-radnych-rozwoju-rzeszowa.

Sikora-Fernandes Dorota, Smart city - nowy trend w rozwoju miast czy moda na kolejna etykietkę?, „Innowacja i Rozwój” 2014, nr 4.

Solski Łukasz, PSL poparło Tadeusza Ferenca $w$ walce o fotel prezydenta Rzeszowa, http://rzeszow.naszemiasto.pl/artykul/psl-poparlo-tadeusza-ferenca-w-walce-o-fotel-prezydenta,618134,art,t,id,tm.html.

Statut Prawa i Sprawiedliwości, Warszawa 2013.

Szczepański Dominik, Wywiad z prezydentem Mielca Danielem Kozdębą, Mielec 24.08.2015.

Tadeusz Ferenc chce być w Senacie. Jest oficjalna decyzja, http://rzeszow-news.pl/tadeusz-ferenc-chce-byc-w-senacie-jest-oficjalna-decyzja.

Tezy miejskie, http://kongresruchowmiejskich.pl/tezy-miejskie.

Wolność, równość, odmienność. Nowe ruchy społeczne w Polsce początku XXI wieku, red. Ireneusz Krzemiński, Warszawa 2006

Żakowska Marta, Ruchy miejskie a tradycja ruchów społecznych, „Animacja Życia Publicznego. Zeszyty Centrum Badań Społeczności i Polityk Lokalnych” 2013, nr 3.

Życzkowska Karolina, Informacyjna warstwa przestrzeni komercyjnej-smart city a wizerunek miasta, Zeszyty Naukowe Uniwersytetu Szczecińskiego, Studia Informatica nr 29, red. A. Szewczyk, Wydawnictwo Naukowe Uniwersytetu Szczecińskiego, Szczecin 2012. 


\title{
Streszczenie
}

Celem artykułu jest przedstawienie pochodzenia i działalności ruchów miejskich, takich jak „Inteligentne miasta” na Podkarpaciu. Ich inicjatorami w Rzeszowie i Mielcu byli lokalni politycy, członkowie SLD. Głównym celem Rzeszów Smart City oraz Mielec Smart City było stymulowanie aktywnego obywatelstwa, inteligentny rozwój, a w przypadku Rzeszowa - także prowadzenie działalności politycznej. Omówiono umieszczenie na Facebooku sztandarowego hasła „Nie przekażę miasta do PiS”, a także deklarację publiczną Konrada Fiołka jako kandydata na stanowisko Prezydenta Miasta Rzeszowa w przedterminowych wyborach. Analizę przeprowadzono w odniesieniu do bezpartyjnych graczy politycznych i oceniano, czy nowo powstające ruchy miejskie obejmują nowoczesną inicjatywę społeczną, a raczej aktywność partii pod zmienioną nazwą.

Słowa kluczowe: ruchy miejskie, ruchy społeczne, województwo podkarpackie

\section{SMART CITY MOVEMENT IN PODKARPACIE. A MODERN SOCIAL INITIATIVE OR POLITICAL ACTIVITY UNDER CHANGED NAME}

\begin{abstract}
The aim of the article was to present origins and activity of city movements, such as smart city in Podkarpacie. Their initiators, both in Rzeszów and Mielec were local politicians, members of Sojusz Lewicy Demokratycznej (Democratic Left Alliance), and the newly created party assumed cross-party profile, associating first and foremost young people. The main aim of Rzeszów Smart City as well as Mielec Smart City was to stimulate active citizenship, intelligent development, and in case of Rzeszów, it was also political activity. It was indicated not only by coining on Facebook the flagship slogan 'We will not hand over the city to PiS', but also the public declaration of Konrad Fiołek as the candidate for the post of the Mayor of Rzeszów in pre-term elections'. The analysis was done with regards to non-party political players and it was evaluated whether the newly-formed city movements comprise a modern social initiative, or rather party activity under changed name.
\end{abstract}

Keywords: urban movements, social movements, subcarpathian voivodeship 
